\title{
Zeolite Farming: A Sustainable Agricultural Prospective
}

\author{
Meharkure Mahesh $^{1}$, Jencymol Thomas ${ }^{1}$, K. Arun Kumar ${ }^{1 *}$, Balkrishna S. Bhople ${ }^{2}$, \\ N.V. Saresh ${ }^{2}$, Sachin K. Vaid ${ }^{3}$ and Sanjat Kumar Sahu ${ }^{4}$ \\ ${ }^{1}$ Department of Agronomy, School of Agriculture, Lovely Professional University, \\ Punjab, India \\ ${ }^{2}$ Regional Research Station, Bhalawal Saukari, PAU, Punjab, India \\ ${ }^{3}$ GB Pant University of Agriculture and Technology, Pantnagar, Uttarakhand, India \\ ${ }^{4}$ Department of Environmental Sciecnces, Sambalpur University, Odisha, India \\ *Corresponding author
}

\section{A B S T R A C T}

\section{Keywords \\ Soil amendment, Soil physical and chemical properties, Fertilizer efficiency \\ Article Info \\ Accepted: \\ 20 April 2018 \\ Available Online: \\ 10 May 2018}

\begin{abstract}
India is a developing nation practicing intensive agriculture for fulfilling the needs of more than eighteen million peoples, for which huge and imbalance amount of fertilizer has been used. Consequently, soil quality deteriorates and inevitable loss of soil microbial diversity. In recent years zeolites a natural aluminosilicate was studied extensively as soil amendment as it increases the soil-nutrient surface area and extend the magnitude of nutrient use efficiency in farming systems. Zeolites types vary in their chemical composition and structure and may have different impact on soil nutrient availability to plants. Slow releases of nutrient, water holding capacity, enhancing soil microbial diversity, ion exchange capacity are the major areas of current research. In this review we present the zeolites types and explored their role in nutrient dynamics.
\end{abstract}

\section{Introduction}

When human started cultivating crops centuries ago the soil was enrich of nutrients and continuous extension of land for agriculture for supply food resulted in insufficiency of soil nutrient and for most of the decades we are unaware of the microbial diversity loss. The ancient people find the reasons behind the fertility decline and they adopted different traditional techniques that improve the fertility of the soil without harming the environment which includes cultivation with rock amendments. The Long term excessive use of agricultural chemicals has altered the fertility of the soil, polluted the environment and water sources and also affected human health (Montemurro et al., 2010). Recently, after discovering the consequences of soil fertility loss, researches are advanced to re-implement the traditional practices to improve soil fertility with logical reasons. A number of organic amendments are used to improve the fertility of soil which not only enhance the soil nutrient availability but also extend the agricultural sustainability. Immobilization of nutrients for longer time in soil led to soil health decline and probably be 
the reason for slower decline in sustainable yield loss.

Zeolites are a valuable gift of nature shaped over millions of years through the interaction of volcanic ash and seawater (Alkaline) under pressure. Since 1960s zeolites are a part of agriculture, due to the usefulness of this rare microporous structure to perform as a soil amendment (Jakkula, 2005) and their distinct cation exchange properties, molecular sieving and adsorption (Mumpton, 1999; Glisic et al., 2009; Hecl and Tóth, 2009). Zeolites are the crystalline, hydrated aluminosilicates of alkali and earth metals that possess infinite threedimensional crystal structure. They are characterized by an ability to lose and gain water reversibly and to exchange some of their component elements without major changes of structure. Zeolite was discovered by Sweedish mineralogist Freiherr Axel Fredrick Cronstedt. He named it Zeolite based on Greek word means A Boiling Stone (zeo-boil, lithosstone). He found zeolite in the copper mine. Zeolites occur in many type of rock mainly in volcaniclastic sediments, the largest and purest deposits are altered victric tuffs. The zeolite is found in Saline, Alkaline lakes; deep sea sediments; low temperature open hydrologic systems; burial digenesis and geothermalhydrothermal system (Hay-Geologic occurrence of zeolites and some associated minerals, 1986). Zeolites have good water holding capacity and soil drainage (Bigelow et al., 2004; Colombani et al., 2015; Huang and Petrovic 1994). Some of the important applications of zeolites are in agriculture, water treatment, gas adsorption, industrial gas separation, aquaculture, animal husbandry, ion exchange and also for order control. Zeolites can absorb up to $55 \%$ water, later this water is used by the plants for their metabolic activities (Pisarovic et al., 2003). Many studies show that Zeolite is not only enable inorganic fertilizer but also it enables organic fertilizers to slowly release their nutrients (Perez-
Caballero et al., 2008). In this concern inclusion of the Zeolite in agriculture for fertilizer management is essential as moreover serving as soil conditioner, it have the ability to increase the crop yield (Noori et al., 2006). Zeolite because of some properties like ability to lose and gain water reversibly by without changing the crystalline structure, Zeolite could be used as a stabilizer, as a chelator, as a fertilizer (Lizidou and Kapetanios, 1992; Perez-Caballero et al., 2008). More than 150 zeolites have been synthesized until now, but Clinoptilolite and Cchabazite are most commonly used Zeolite (Polat et al., 2004). A Zeolite has been classified on the basis of its morphological characteristics, its chemical composition, its crystalline structure, its effective pore diameter, its natural occurrence, etc. In the year 1997, International Mineralogical Association Commission on New Minerals and Mineral Names recommended nomenclature for Zeolite minerals. The commission report suggested that Zeolite species are not to be distinguished solely on the ratio of $\mathrm{Si}$ to $\mathrm{Al}$, except only for Heulandite ( $\mathrm{Si}: \mathrm{Al}<4.0$ ) and Clinoptilolite (Si: $\mathrm{Al} \geq 4.0$ ). For recognizing separate species of Zeolite dehydration, partial hydration and over hydration are not sufficient (Coombs et al., 1997).

Among natural zeolite most common and most studied mineral is Clinoptilolite, not only because of its high occurrence in nature and the lowest price but also of its unique physiochemical properties. Clinoptilolite improves nitrogen fertilization efficiencies and also reduces nitrate leaching by inhibiting the nitrification of ammonia to nitrate (Perrin et al., 1998). Zeolites are having a long history but commercially it produces from 1960 (Polat et al., 2004). According to reports the total zeolite consumption was 3.1 million tons in which the natural sources added $18 \%$ and remaining coming from the synthetic sources like A, X, ZMS5 (Oz et al., 2003). Zeolite has 
three main properties which are of great interest for agriculture purpose. Zeolite has high cation exchange properties; having high water holding capacity; having high adsorption properties (Mumpton, 1999). Zeolite improves the efficiency of water use by increasing the water holding capacity of soil and its availability to plant (Bernardi et al., 2010). In India acidic soil Problem is arises in great rate, here also the Zeolite helping farmers by increasing soil $\mathrm{pH}$. Filcheva and Tsadilas in their experiment on Influence of Clinoptilolite and Compost on soil properties find concluded that Zeolite increased the soil $\mathrm{pH}$ and exchangeable Potassium (K). Application of natural Zeolite in radish cultivation seems that it increases the final yield and also retain the harmful salt, because that salt does not pass through roots to the plants (Noori et al., 2007).

\section{Zeolite availability and classification}

In India, zeolites are found in various states likes Maharashtra, Madhya Pradesh, Tamilnadu, Andhra Pradesh, and Karnataka. The region of Deccan plateau in Black soil region, Indo Gangetic plain region contain the $98 \%$ and $2 \%$ of the area respectively under the zeolite in India which is approx 2.8 million (Bhattacharyya et al., 2015) and specifically western India having more Zeolite than any other region of India. In western India particularly Pune, Nashik, Mumbai, Baroda are having zeolite deposition in Sahyandri mountains. More than 80 different species of this mineral group have been identified and still more coming to be identified (Ramesh et al., 2015). Zeolites are classified on the basis of their morphological characteristics, crystal structure, chemical composition, effective pore diameter, natural occurrence, etc. The subcommittee on zeolites of the International Mineralogical Association Commission in the year 1997 on New Minerals and Mineral Names has recommended nomenclature for zeolite minerals (Ramesh and Reddy 2011). The recent research suggested that zeolite species are not distinguished only on the ratio of $\mathrm{Si}$ to $\mathrm{Al}$, except for Heulandite (Si: $\mathrm{Al}<$ 4.0) and Clinoptiliolite ( $\mathrm{Si}: \mathrm{Al} \geq 4.0)$ (Ramesh and Reddy 2011). According to Coombs et al., dehydration, partial hydration and overhydration are not adequate or enough for the recognition of separate species of zeolites. Zeolites are classified on the basis of Silica: Alumina ratio as (Ramesh and Reddy 2011)-

Zeolites with low Si: Al ratio (1.0 to 1.5 )

Zeolites with intermediate Si: Al ratio (2 to 5)

Zeolites with high Si: Al ratio (10 to several thousands).

\section{Significance of zeolite in agriculture}

The increased number of population creates scarcity of food and poverty. Due to the increase in population and modernization, the agricultural lands are converting in to buildings. In this situation, there is only a chance to feed the large number of population. That is to produce more from small pieces of land. Zeolite is a natural nano particle which helps to achieve this mission. There are over 40 known natural zeolites. From this seven of them are being found (clinoptilolite, chabazite, mordenite, erionite, ferrierite, analcime, philipsite). From this clinoptilolite is commonly used due to its cheap price as well as the physiochemical properties (Hubicki et al., 2000; Szerement et al., 2014). Zeolites are used in mineral fertilizer industry as slow release and as carriers of active ingredients. The application of zeolite to the fertilizers is to retain the nutrients for longer time. The applied nutrients are released in the first year and the following years. This also helps to reduce leaching of nutrients from the soil layers so that the amount of fertilizer applied can be reduced (DeLuca and DeLuca, 1997). 
Application of zeolite mainly helps to control the leaching of different forms of nitrogen in the soil. Another importance is that it can maintain the water balance of the soil. That is, due to its porous structure it can hold more water. This property can be utilized in water scares area. (Ghanbari and Ariafar, 2013) has proved that application of zeolite has a significant effect on essential oil yield and medicinal peppermint. Zeolites are also used for animal nutrition and health. According to the project conducted by (Filizova, 1993) and (Onagi, 1966) showed that the rations of $15 \%$ clinoptilolite fed to young and mature pigs gained $16 \%$ more weight than the pigs fed by normal diet. The feeding of zeolites to animals also helps to reduce the intestinal diseases of animals. Zeolites are used as artificial soil. The cultivation of crops with the artificial soil containing zeolite with or without peat, vermiculate etc are termed as zeoponics (Mumpton, 1999). It also plays an important role in Aquaculture. It can be used mainly for removing ammonium from aquarium water, to maintain the oxygen level for aeration and also as a supplement of fish rations. The use of zeolite in soil reclamation is another important use of this nano particle in agriculture. The zeolite can increase the $\mathrm{pH}$ of the acidic soil (Szerement et al., 2014). Many soils are amended with zeolites for improving the physical, chemical and biological properties of the soil. In general, we can say that zeolites are essential for agriculture now days as well as future.

\section{Zeolite as a soil amendment}

Farmers specifically in developing nations use water and fertilizers intensively and the continuous use of ground water deplete the ground water table day by day and soil moisture holding capacity also depletes (Zalidis et al., 2002). Also because of the environment change there is irregularities in rainfall, because of this the certain situation like drought occurs. So, for this there is urgent need of the cheapest sources of water conservation because in country like India where farmers are not so economically capable to purchase high cost water conservation sources, the possible solution is application of zeolites as soil amendment. Zeolites are micro porous, crystalline alluminosilicate of alkali and alkaline materials with high internal surface area. Because of that such can reduce losing soil in arid and semi arid regions by soil improving soil physically. These are like storage tank which absorbs the water provided through irrigation and rainfall and reduced the permeability of soil. Zeolite improve the lateral spread of water into the root zone during irrigation (Polat et al., 2004) and in drought stress condition water saved in the polymer is gradually adopted and limit need for re irrigation.

The changes in soil physical properties carried out by addition of Zeolites in the large-scale test lead to increase in the soil water retention capacity and also decrease the percolation (Colombani et al., 2015). Zeolite application in lands which are exposes to late sown drought stress can keep soil water content and improve plant growth with production ( $\operatorname{Rad}$ and Abbasian, 2011). Zeolite not only increases the water holding capacity but also increase the effect of mineral fertilizers (Shinde et al., 2010). Zeolites use in acid soil has beneficial effect on maize and improved the Nitrogen, Phosphorous, Potassium uptake (Ahmed et al., 2010). Unlike other soil amendment like lime zeolites does not break down over time but retain in the soil for improving nutrient retention. Because of the porous structure of natural zeolites which helps to keep the soil aerated and moist as well as active for long period of time. Zeolite is not acidic in nature but marginally alkaline and if amended with fertilizers can help buffer soil $\mathrm{pH}$ levels and may reduce the lime 
requirement. Zeolites retain the valuable nitrogen and improve the quality of the resulting manures and sludge and can also be use like a molecular sieve or like filter medium (Polat et al., 2004). Zeolite can absorbs $\mathrm{CO}_{2}, \quad \mathrm{SO}_{2}, \mathrm{H}_{2} \mathrm{~S}, \quad \mathrm{NH}_{3}, \mathrm{HCHO}$ (formaldehyde), $\mathrm{O}_{2}, \mathrm{~N}_{2}, \mathrm{H}_{2} \mathrm{O}, \mathrm{CH}_{3} \mathrm{OH}$ and many more gasses and can thus be used to collect them or control odurs (Polat et al., 2004). Zeolite has the highest binding capacity between pH $5-6.5$ and was stable >pH5.5 (Oste et al., 2002). Zeolites also have the great effect on salinity of soil, soil amended with zeolite could effectively ameliorate, Salinity stress and improve the nutrient balance in a sandy soil (Al-Busaidi et al., 2008). The CEC (Cation Exchange Capacity) is one of the major property of soil which influence the fertility of soil. There will be more CEC more is the soil fertility and by this more will be the production. Zeolite amendment is helps in increasing the CEC of soil (DeSutter and Pierzynski 2005). Soil microbial population is also one the major part of soil. More soil microbial population lead to the faster rate of decomposition of the soil organic matter. Many soil micro organisms are respond zeolites amendment in different ways (Muhlbachova and Simon 2003). There is a lot of potential for compound fertilizer with zeolite to improve nitrogen efficiency by lowering down the ammonium vitalization and increasing accumulation of exchangeable NH4 and $\mathrm{NO}_{3}-$. Fertilizers formulated with zeolites at higher amount effectively reduce the ammonium volatilization as compared to commercial compound fertilizer and ammonium nitrate (Lija et al., 2012). The experiment on Brassica alboglabra found that Ammonium and Potassium loaded zeolites can reduce loss of nutrient to the ground water and to the environment ( $\mathrm{Li}$ et al., 2013). The research on effect of Ammonium zeoliteX on maize shows significant increase in growth of maize crop.

\section{Zeolite and nutrient use efficiency}

Nutrient use efficiency can be explained as the yield which is produced by unit input applied. In other words, the product yields per nutrient content present. The nutrients present in the soil can be loss by different ways like volatilization, leaching, runoff etc. Most of the soils in the world are deficient of one or more nutrients due to the over cultivation, or by natural losses. Sometimes the nutrient available in the soil cannot be taken up by the plants due to some environmental problems or some other problems. Nutrient use efficiency also depends on the effectiveness of the plant to take up the nutrients from the soil but also on movement of nutrients to the plant, mobilization, storage, usage by the plant and even the environment.

So, it is very essential to improve the nutrient use efficiency. Improving nutrient use efficiency can increase crop productivity. But it should be without harming the environment.

Zeolites can enhance the efficiency of nutrient use by increasing the accessibility of $\mathrm{P}$ from phosphate rocks, and the consumption of $\mathrm{NH}_{4}$, $\mathrm{N}$ and $\mathrm{NO}_{3}$, reduce loss by leaching of $\mathrm{k}^{+}$and also act as a slow releaser of fertilizer without harming the environment (Allen et al., 1993; Barbarick et al., 1990). The use of zeolites could be beneficial for retention of nutrient in soil and their use efficiency. Thus, the use of zeolites in acid soil where the nutrient not retain, is useful in maize cultivation (Ahmed et al., 2010).

Plant biomass is important indicator of ecological and management process in vegetation. The addition of trivalent chromium in the soil has been showing that Zeolite is the only soil amendment that increased the dry weight of biomass of plant. Zeolite as soil amendment reduced significantly the total chromium in plants (Molla et al., 2015). 
Table.1 Zeolite with structure, color, year of discovery- table-different zeolites with their groups (http://www.mindat.org/min-4395.html)

\begin{tabular}{|l|}
\hline Group and Group member \\
\hline Alflarsenite \\
\hline$\underline{\text { Amicite }}$ \\
\hline Ammonioleucite \\
\hline$\underline{\text { Analcime }}$ \\
\hline Bellbergite \\
\hline Barrerite \\
\hline Bikitaite \\
\hline Boggsite \\
\hline Brewsterite-Ba \\
\hline Brewsterite-Sr \\
\hline Chabazite-Ca \\
\hline Chabazite-K \\
\hline Chabazite-Mg \\
\hline Chabazite-Na \\
\hline Chabazite-Sr \\
\hline Chiavennite \\
\hline Clinoptilolite-Ca \\
\hline Clinoptilolite-K \\
\hline Clinoptilolite-Na \\
\hline Cowlesite \\
\hline Dachiardite-Ca \\
\hline Dachiardite-K \\
\hline
\end{tabular}

\begin{tabular}{|c|c|c|}
\hline Year of Discovery & Structure & Color \\
\hline 1969 & $\mathrm{NaCa}_{2} \mathrm{Be}_{3} \mathrm{Si}_{4} \mathrm{O}_{13}(\mathrm{OH}) \cdot 2 \mathrm{H}_{2} \mathrm{O}$ & Colorless \\
\hline 1979 & $\mathrm{~K}_{2} \mathrm{Na}_{2} \mathrm{Al}_{4} \mathrm{Si}_{4} \mathrm{O}_{16} \cdot 5 \mathrm{H}_{2} \mathrm{O}$ & Colorless \\
\hline 1986 & $\left(\mathrm{NH}_{4}, \mathrm{~K}\right)\left(\mathrm{AlSi}_{2} \mathrm{O}_{6}\right)$ & White \\
\hline 1797 & $\mathrm{Na}\left(\mathrm{AlSi}_{2} \mathrm{O}_{6}\right) \cdot \mathrm{H}_{2} \mathrm{O}$ & White, colorless, gray, \\
\hline 1993 & $(\mathrm{~K}, \mathrm{Ba}, \mathrm{Sr})_{2} \mathrm{Sr}_{2} \mathrm{Ca}_{2}(\mathrm{Ca}, \mathrm{Na})_{4}\left[\mathrm{Al}_{3} \mathrm{Si}_{3} \mathrm{O}_{12}\right]_{6} \cdot 30 \mathrm{H}_{2} \mathrm{O}$ & Colorless to white \\
\hline 1974 & $\left(\mathrm{Na}, \mathrm{K}, \mathrm{Ca}_{0.5}\right)_{2}\left[\mathrm{Al}_{2} \mathrm{Si}_{7} \mathrm{O}_{18}\right] \cdot 7 \mathrm{H}_{2} \mathrm{O}$ & White, Pink \\
\hline 1957 & $\mathrm{LiAlSi}_{2} \mathrm{O}_{6} \cdot \mathrm{H}_{2} \mathrm{O}$ & Colorless, White \\
\hline 1990 & $\mathrm{Ca}_{8} \mathrm{Na}_{3}(\mathrm{Si}, \mathrm{Al})_{96} \mathrm{O}_{192} \cdot 70 \mathrm{H}_{2} \mathrm{O}$ & Colorless, White \\
\hline - & $(\mathrm{Ba}, \mathrm{Sr})\left[\mathrm{Al}_{2} \mathrm{Si}_{6} \mathrm{O}_{16}\right] \cdot 5 \mathrm{H}_{2} \mathrm{O}$ & White, Colorless, Pale pink \\
\hline & $(\mathrm{Sr}, \mathrm{Ba}, \mathrm{Ca})\left[\mathrm{Al}_{2} \mathrm{Si}_{6} \mathrm{O}_{16}\right] \cdot 5 \mathrm{H}_{2} \mathrm{O}$ & White \\
\hline 1788 & $\left(\mathrm{Ca}, \mathrm{K}_{2}, \mathrm{Na}_{2}\right)_{2}\left[\mathrm{Al}_{2} \mathrm{Si}_{4} \mathrm{O}_{12}\right]_{2} .12 \mathrm{H}_{2} \mathrm{O}$ & Colorless, white, yellow, pink, red \\
\hline 1788 & $\left(\mathrm{~K}_{2}, \mathrm{Ca}, \mathrm{Na}_{2}, \mathrm{Sr}, \mathrm{Mg}\right)_{2}\left[\mathrm{Al}_{2} \mathrm{Si}_{4} \mathrm{O}_{12}\right]_{2} \cdot 12 \mathrm{H}_{2} \mathrm{O}$ & Colorless \\
\hline 1788 & $\left(\mathrm{Mg}_{0.7} \mathrm{~K}_{0.5} \mathrm{Ca}_{0.5} \mathrm{Na}_{0.1}\right)\left[\mathrm{Al}_{3} \mathrm{Si}_{9} \mathrm{O}_{24}\right] \cdot 10 \mathrm{H}_{2} \mathrm{O}$ & Colorless \\
\hline 1788 & $\left(\mathrm{Na}_{2}, \mathrm{~K}_{2}, \mathrm{Ca}, \mathrm{Sr}, \mathrm{Mg}\right)_{2}\left[\mathrm{Al}_{2} \mathrm{Si}_{4} \mathrm{O}_{12}\right]_{2} \cdot 12 \mathrm{H}_{2} \mathrm{O}$ & Colorless \\
\hline - & $\mathrm{Sr}_{2}\left[\mathrm{Al}_{2} \mathrm{Si}_{4} \mathrm{O}_{12}\right]_{2} \cdot 12 \mathrm{H}_{2} \mathrm{O}$ & Colorless \\
\hline- & $\mathrm{CaMnBe}_{2} \mathrm{Si}_{5} \mathrm{O}_{13}(\mathrm{OH})_{2} \cdot 2 \mathrm{H}_{2} \mathrm{O}$ & Colorless \\
\hline \multirow[t]{3}{*}{-} & $(\mathrm{Ca}, \mathrm{Na}, \mathrm{K})_{2-3} \mathrm{Al}_{3}\left(\mathrm{Al}, \mathrm{Si}_{2}\right)_{2} \mathrm{Si}_{13} \mathrm{O}_{36} \cdot 12 \mathrm{H}_{2} \mathrm{O}$ & - \\
\hline & $(\mathrm{K}, \mathrm{Na}, \mathrm{Ca})_{2-3} \mathrm{Al}_{3}\left(\mathrm{Al}, \mathrm{Si}_{2}\right)_{2} \mathrm{Si}_{13} \mathrm{O}_{36} \cdot 12 \mathrm{H}_{2} \mathrm{O}$ & \\
\hline & $(\mathrm{Na}, \mathrm{K}, \mathrm{Ca})_{2-3} \mathrm{Al}_{3}(\mathrm{Al}, \mathrm{Si})_{2} \mathrm{Si}_{13} \mathrm{O}_{36} \cdot 12 \mathrm{H}_{2} \mathrm{O}$ & \\
\hline \multirow[t]{3}{*}{1975} & $\mathrm{CaAl}_{2} \mathrm{Si}_{3} \mathrm{O}_{10} \cdot 6 \mathrm{H}_{2} \mathrm{O}$ & Colorless, White \\
\hline & $\left(\mathrm{Ca}, \mathrm{Na}_{2}, \mathrm{~K}_{2}\right)_{5} \mathrm{Al}_{10} \mathrm{Si}_{38} \mathrm{O}_{96} \cdot 25 \mathrm{H}_{2} \mathrm{O}$ & \\
\hline & $\mathrm{K}_{4}\left(\mathrm{Si}_{20} \mathrm{Al}_{4} \mathrm{O}_{48}\right) \cdot 13 \mathrm{H}_{2} \mathrm{O}$ & Snow-white \\
\hline
\end{tabular}




\begin{tabular}{|l|}
\hline Dachiardite-Na \\
\hline$\underline{\text { Direnzoite }}$ \\
\hline$\underline{\text { Edingtonite }}$ \\
\hline Epistilbite \\
\hline Erionite-Ca \\
\hline Erionite-K \\
\hline Erionite-Na \\
\hline Faujasite Subgroup \\
\hline Faujasite-Ca \\
\hline Faujasite-Mg \\
\hline Faujasite-Na \\
\hline Ferrierite \\
\hline Ferrierite-K \\
\hline Ferrierite-Mg \\
\hline Gismondine \\
\hline Gismondine-Ba \\
\hline Gismondine-Ca \\
\hline Gmelinite \\
\hline Gmelinite-Ca \\
\hline Gmelinite-K \\
\hline Heulandite-Ba \\
\hline Phillipsite-Ca \\
\hline
\end{tabular}

\begin{tabular}{|c|c|c|c|}
\hline & $\left(\mathrm{Na}_{2}, \mathrm{Ca}, \mathrm{K}_{2}\right)_{5} \mathrm{Al}_{10} \mathrm{Si}_{38} \mathrm{O}_{96} \cdot 25 \mathrm{H}_{2} \mathrm{O}$ & & \\
\hline & $\mathrm{NaK}_{6} \mathrm{MgCa}_{2}\left(\mathrm{Al}_{13} \mathrm{Si}_{47} \mathrm{O}_{120}\right) \cdot 36 \mathrm{H}_{2} \mathrm{O}$ & & Colorless \\
\hline & $\mathrm{Ba}\left[\mathrm{Al}_{2} \mathrm{Si}_{3} \mathrm{O}_{10}\right] \cdot 4 \mathrm{H}_{2} \mathrm{O}$ & & \\
\hline & $\mathrm{CaAl}_{2} \mathrm{Si}_{6} \mathrm{O}_{16} \cdot 5 \mathrm{H}_{2} \mathrm{O}$ & & Colorless, white, pinkish, yellowish \\
\hline \multirow[t]{8}{*}{1898} & $\left(\mathrm{Ca}, \mathrm{K}_{2}, \mathrm{Na}_{2}\right)_{2}\left[\mathrm{Al}_{4} \mathrm{Si}_{14} \mathrm{O}_{36}\right] \cdot 15 \mathrm{H}_{2} \mathrm{O}$ & & White \\
\hline & $\left(\mathrm{K}_{2}, \mathrm{Ca}, \mathrm{Na}_{2}\right)_{2}\left[\mathrm{Al}_{4} \mathrm{Si}_{14} \mathrm{O}_{36}\right] \cdot 15 \mathrm{H}_{2} \mathrm{O}$ & & \\
\hline & $\left(\mathrm{Na}_{2}, \mathrm{~K}_{2}, \mathrm{Ca}\right)_{2}\left[\mathrm{Al}_{4} \mathrm{Si}_{14} \mathrm{O}_{36}\right] \cdot 15 \mathrm{H}_{2} \mathrm{O}$ & & \\
\hline & $\left(\mathrm{Ca}, \mathrm{Na}_{2}, \mathrm{Mg}\right)_{3.5}\left[\mathrm{Al}_{7} \mathrm{Si}_{17} \mathrm{O}_{48}\right] \cdot 32 \mathrm{H}_{2} \mathrm{O}$ & & \\
\hline & $\left(\mathrm{Mg}, \mathrm{Na}_{2}, \mathrm{Ca}\right)_{3.5}\left[\mathrm{Al}_{7} \mathrm{Si}_{17} \mathrm{O}_{48}\right] \cdot 32 \mathrm{H}_{2} \mathrm{O}$ & & \\
\hline & $\left(\mathrm{Na}_{2}, \mathrm{Ca}, \mathrm{Mg}\right)_{3.5}\left[\mathrm{Al}_{7} \mathrm{Si}_{17} \mathrm{O}_{48}\right] \cdot 32 \mathrm{H}_{2} \mathrm{O}$ & & \\
\hline & $\left(\mathrm{K}_{2}, \mathrm{Na}_{2}, \mathrm{Mg}, \mathrm{Ca}\right)_{3-5} \mathrm{Mg}\left[\mathrm{Al}_{5-7} \mathrm{Si}_{27.5-31} \mathrm{O}_{72}\right]$ & $\cdot 18 \mathrm{H}_{2} \mathrm{O}$ & \\
\hline & $\left(\mathrm{Mg}, \mathrm{Na}_{2}, \mathrm{~K}_{2}, \mathrm{Ca}\right)_{3-5} \mathrm{Mg}\left[\mathrm{Al}_{5-7} \mathrm{Si}_{27.5-31} \mathrm{O}_{72}\right]$ & $\cdot 18 \mathrm{H}_{2} \mathrm{O}$ & \\
\hline \multirow[t]{7}{*}{1817} & & & Colorless to white, very pale pink. \\
\hline & $\mathrm{Ba}_{2} \mathrm{Al}_{4} \mathrm{Si}_{4} \mathrm{O}_{16} \cdot 4-6 \mathrm{H}_{2} \mathrm{O}$ & & \\
\hline & $\mathrm{CaAl}_{2} \mathrm{Si}_{2} \mathrm{O}_{8} \cdot 4 \mathrm{H}_{2} \mathrm{O}$ & & \\
\hline & $\mathrm{Ca}_{2}\left(\mathrm{Si}_{8} \mathrm{Al}_{4} \mathrm{O}_{24}\right] \cdot 11 \mathrm{H}_{2} \mathrm{O}$ & & \\
\hline & $\mathrm{K}_{4}\left(\mathrm{Si}_{8} \mathrm{Al}_{4} \mathrm{O}_{24}\right) \cdot 11 \mathrm{H}_{2} \mathrm{O}$ & & \\
\hline & $(\mathrm{Ba}, \mathrm{Ca}, \mathrm{K}, \mathrm{Na}, \mathrm{Sr})_{5} \mathrm{Al}_{9} \mathrm{Si}_{27} \mathrm{O}_{72} \cdot 22 \mathrm{H}_{2} \mathrm{O}$ & & \\
\hline & $\begin{array}{l}\left(\mathrm{Ca}_{0.5}, \mathrm{~K}, \mathrm{Na}, \mathrm{Ba}_{0.5}\right)_{4-7}\left[\mathrm{Al}_{4-7} \mathrm{Si}_{12-9} \mathrm{O}_{32} .\right. \\
12 \mathrm{H} 2 \mathrm{O}\end{array}$ & & \\
\hline
\end{tabular}


Fig.1 Types of Zeolite -A- Alflarsenite, B- Amicite, C- Ammonioleucite, D- Analcime, EBarrerite, F- Bellbergite, G- Bikitaite, H- Boggsite, I- Brewsterite-Ba, J- Brewsterite-Sr, KChabazite-Ca, L- Chabazite- K, M- Chabazite-Mg, N- Chabazite-Na, O- Chabazite-Sr, PChiavennite, Q- Clinoptilolite-Ca, R- Clinoptilolite-K, S- Clinoptilolite-Na, T- Cowlesite, UDachiardite-Ca, V-Dachiardite-Na, W-Edingtonite, X-Epistilbite, Y-Erionite-Ca, Z-Erionite-K, Aa-Erionite-Na, Bb-Faujasite-Ca, Cc-Faujasite-Mg, Dd-Gsmondine-Ca, Ee-Gamelnite-Ca, Ff-

Heulandite-Ba, Ii-Heulandite-Ca, Jj-Phillipsite-ca. Source: http://www.mindat.org/min4395.html

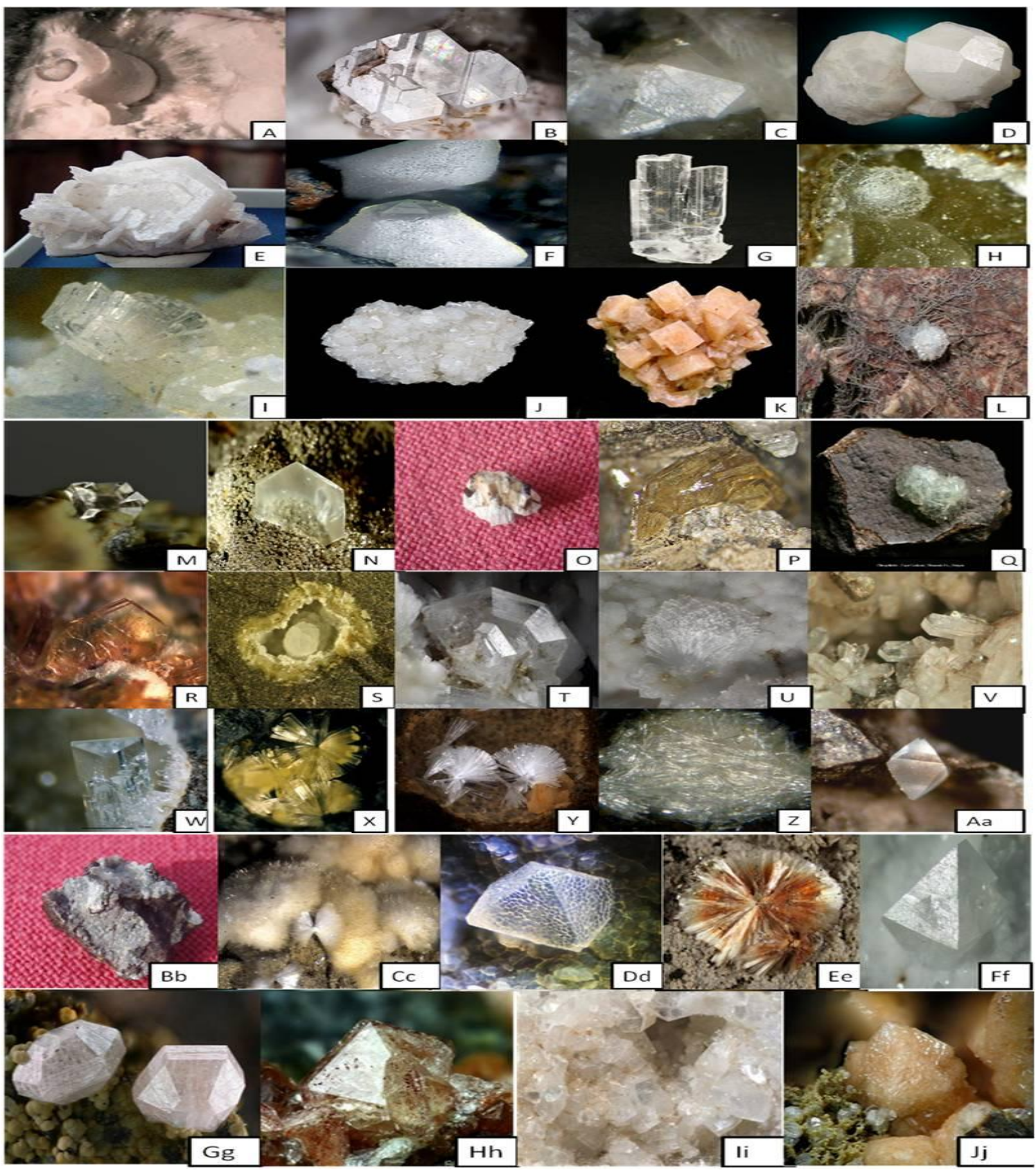


Nitrogen is critical limiting factor in plant which determines the yield. Availability of Nitrogen is subjected to the quality and quantity of soil organic matter amendment. Most of the nitrogen is leached down in soil because of various reasons like leaching. Surface and ground water are contaminated because of leaching of nitrogen (Costa et al., 2000). Use of soluble Nitrogenous fertilizer is one of the reasons for ground water contamination (Ramesh et al., 2010). For that to hold the nitrogen in soil Zeolite is going to give great opportunity. The nitrogen molecules are retained by electrostatic attraction, modification of molecular angles, single and double bonds occur in Zeolite (Park and Komarnent, 1998). Pores in clinoptilolite framework are so small for cations like ammonium and potassium to enter but to large for nitrifying bacteria to enter means ammonia after holding by cation exchange sites within the clinoptilolite is not to be leached easily as water passes through it (Ramesh et al., 2010). Clinoptilolite not only improves the Nitrogen fertilization efficiencies but also reduces nitrate leaching by inhibiting the nitrification of ammonium to nitrate (Perrin et al., 1998). Zeolite use with the cattle manure reduces the nitrate leaching (Gholamhoseini et al., 2013). In sandy soil where nitrogen leaching problems are more there use of zeolite (Clinoptilolite) reduced the Nitrogen loss (He et al., 2002). Zeolite application in rice field not only increases the yield but also increase Nitrogen retention in second year (Sepaskhah and Barzegar, 2010). The total Phosphorus concentration in Agricultural crop varies from 0.1 to 0.5 percent generally. Phosphorus plays a very important role in the energy transfer process of plant and a very important component of gene and chromosomes. Movement of nutrients within the plant requires energy to oppose the forces of osmosis during the transportation through cell. For this ATP and other high energy phosphorus compounds provide the energy. Zeolite has shown their ability to increase the solubalization of phosphate minerals leading to improved Phosphorus uptake and yield of crop (Ramesh et al., 2010). Ammonium charged zeolites shows that they increased the solubalization of bone ash of animal which mainly contain the Phosphorus (Lancellotti et al., 2014) and also increased the solubility of Rock Phosphate (Allen et al., 1993).

\section{Zeolite impact on other soil properties}

Zeolites as soil amendment enhance soil physical, chemical and biological properties. Zeolite increases the soil $\mathrm{pH}$ and exchangeable Potassium and helps in enhancing salt and water holding capacity of the soil (Filcheva and Tsadilas 2002). Postharvest analysis of the soil shows that there is high concentration of Calcium, Magnesium, Sodium, and Potassium ions due to saline water specially in upper layer of soil, but the soil treated with zeolites having lower concentration of the above minerals. Zeolite application at 5\% increased Calcium concentration in plant stressed with salt where for Magnesium and Iron the zeolites increased should be $10 \%$ and $19 \%$ respectively. That's why Zeolite could effectively ameliorate salinity stress and improve the nutrient balance in a sandy soil (Al-Busaidi et al., 2008). Application of Zeolite in grey forest loamy soil improved the agrochemical properties of this type of soil (Yapparov et al., 2015). The ideal bulk density for optimum crop growth varies from $1.2 \mathrm{gm} / \mathrm{cm}^{3}$ for clay soil and $1.4 \mathrm{gm} / \mathrm{cm}^{3}$ for a sandy soil. Bulk Density of the zeolites and sand mixture ranged from 1.37 to $1.42 \mathrm{gm} / \mathrm{cm}^{3}$, which are significantly lower than unamended sand (Huang and Petrovic, 1994). Zeolite also promoted the formation of soil aggregate that increase in soil porosity and decreasing soil bulk density and improving the output of crops (Xiliang et al., 1991). 
Soil microorganism plays vital role in organic matter decomposition and soil fertility. Higher the rate of soil microorganism in soil higher is the rate of decomposition of organic matter in soil. Research shows that total number of bacteria, the microscopic fungi, and nitrifying bacteria increased by addition of $30 \%$ of zeolite treated soil (Katai et al., 2010). However, studies related to impact of zeolites as soil amendment on soil microbial diversity is very limited.

Intensive and imbalance use of fertilizers has severe negative impact on soil quality. And in this scenario, it is an urgent need to explore the possibility of different soil amendment to improve soil quality. In this review significant positive impact of zeolites as soil amendment are discussed. Extensive research is required to explore the zeolites farming is required; consequently, it may enhance agricultural sustainability in India.

\section{References}

Ahmed, O.H., Sumalatha, G., Muhamad, A.M.N., Use of zeolite in maize (Zea mays) cultivation on nitrogen, potassium and phosphorus uptake and use efficiency, International Journal of the Physical Sciences Vol. 5(15), pp. 2393-2401, 18 November, (2010).

Al-Busaidi, A., Yamamoto, T., Inoue, M., Eneji, A.E., Mori, Y. and Irshad, M., Effects of zeolite on soil nutrients and growth of barley following irrigation with saline water. J. Plant Nutrition, 31(7), 1159-1173 (2008).

Allen, E.R., Hossner, L.R., Ming, D.W. and Henninger, D.L., Solubility and cation exchange in phosphate rock and saturated clinoptilolite mixtures. Soil. Sci. Soc. Am. J., 57(5), 1368-1374 (1993).

Barbarick, K. A., Lai, T. M., and Eberl, D. D. Exchange fertilizer (phosphate rock plus ammonium-zeolite) effects on sorghumsudangrass. Soil Science Society of America Journal, 54(3), 911-916 (1990).

Bernardi, AC de C., SOUZA, S., CARDOSO, R.D., and OLIVEIRA, P.P.A., Ammonia volatilization, dry matter yield and nitrogen levels of Italian ryegrass fertilized with urea and zeolite. Embrapa Pecuária SudesteArtigoemanais de congresso (ALICE). World Congress of Soil Science, 19, (2010).

Bhattacharyya, T., Chandran, P., Ray, S.K., Pal, D.K., Mandal, C. and Mandal, D.K., Distribution of zeolitic soils in India. Current Science, 109(7), 13051313 (2015).

Bigelow, C.A., Bowman, D.C. and Cassel, D.K., Physical properties of three sand size classes amended with inorganic materials or sphagnum peat moss for putting green root zones. Crop Science, 44(3), pp. 900-907 (2004).

Colombani, N., Mastrocicco, M. and Giambastiani, B.M.S., Predicting salinization trends in a lowland coastal aquifer: Comacchio (Italy). Water Resources Management, 29(2), pp.603618 (2015).

Coombs, D.S., Alberti, A., Armbruster, T., Artioli, G., Col, C., Galli, E., Grice, Friedrich Liebau, F., Mandarino, J.A., Minato, H., Nickel, E.H., Passaglia, E., Peacor, D.R., Quartieri, S., Rinaldi, R., Ross, M., Sheppard, R.A., Tillmanns, E., Vezzalini, G., Recommended Nomenclature For Zeolite Minerals: Report Of The Subcommittee On Zeolites of The International Mineralogical Association, Commission On New Minerals and Mineral Names, The Canadian Mineralogist Vol. 35, pp. 1571-1606 (1997).

Costa, J. L., Ambiente, R.Y.M., Caldiad de agaus para riego. Paginas 7-14. En: 
Seminario de Riego. Regional Buenos Aires Sur (ed.), Estaction Experimental Agropecuaria Balcarce, INTA, Mar del Plata, Argentina, (2000).

DeLuca, T.H. and DeLuca, D.K., 1997. Composting for feedlot manure management and soil quality. Journal of Production Agriculture, 10(2), pp.235241.

DeSutter, T.M., and Pierzynski G.M., Evaluation of Soils for Use as Liner Materials. Journal of environmental quality 34, no. 3: 951-962 (2005).

Filcheva, E. G., and Tsadilas, C. D. Influence of clinoptilolite and compost on soil properties. Communications in soil science and plant analysis, 33(3-4), 595-607 (2002).

Filizova, L. J. U. D. M. I. L. A., Petrova, N. A. D. I. A., and Kirov, G. Ion exchange of clinoptilolite in solution with different concentration: a calorimetric study. Geologica Carpathica-Series Clays, 44, 31-34 (1993).

Ghanbari, M. and Ariafar, S., 2013. The Effects of Water Deficit and Zeolite Application on Growth Traits and Oil yield of Medicinal Peppermint (Mentha piperita L). Int J MedArom. Plants, 3(1), pp.32-39.

Gholamhoseini, M., Ghalavand, A., Joghan, A.K., Dolatabadian, A., Zakikhani, H., and Farmanbar, E., Zeolite-amended cattle manure effects on sunflower yield, seed quality, water use efficiency and nutrient leaching. Soil and Tillage Research 126: 193-202 (2013).

Glisic, I.P., Milosevic, T.M., Glisic, I.S. and Milosevic, N.T., 2009. The effect of natural zeolites and organic fertilisers on the characteristics of degraded soils and yield of crops grown in Western Serbia. Land degradation \& development, 20(1), pp.33-40.

Hay, R.L., 1986. Geologic occurrence of zeolites and some associated minerals.
Pure and Applied Chemistry, 58(10), pp.1339-1342.

He, Z. L., Calvert, D. A., Alva, A. K., Li, Y. C., Banks. D. J., Clinoptilolite zeolite and cellulose amendments to reduce ammonia volatilization in calcareous sandy soil, Plant and Soil 247: 253-260, (2002).

Hecl, J., and Tóth, S., Effect of fertilizers and sorbents applied to the soil on heavy metal transfer from the soil. Electronic Journal of Polish Agricultural Universities, 12(2), (2009).

http://www.mindat.org/min-4395.html

Huang, Z.T. and Petrovic, A.M., 1994a. Clinoptilolite zeolite influence on nitrate leaching and nitrogen use efficiency in simulated sand based golf greens. Journal of Environmental Quality, 23(6), pp.1190-1194.

Huang, Z.T. and Petrovic, A.M., Physical properties of sand as affected by clinoptilolite zeolite particle size and quantity. Journal of Turfgrass management, 1(1), pp.1-15 (1994b).

Hubicki, Z., and M. Olszak. Studies of the separation of nitrate complexes of samarium (III) from neodymium (III) in the $\mathrm{C}_{2} \mathrm{H}_{5} \mathrm{OH}-7 \mathrm{M} \mathrm{HNO}_{3}$ system on the strongly basic anion exchanger Wofatit SBW." Adsorption Science \& Technology 18, no. 8: 701-707 (2000).

Jakkula, Vijay S., Synthesis of zeolites and their application as soil amendments to increase crop yield and potentially act as controlled release fertilizers (2005).

Kátai, J., Tállai, M., Sándor, Z. and OláhZsuposné, Á., 2010. Effect of bentonite and zeolite on some characteristics of acidic sandy soil and on the biomass of a test plant. Agrokémiaés Talajtan, 59(1), pp. 165174.

Lancellotti, I., Toschi, T., Passaglia, E., and Barbieri, L. Release of agronomical nutrient from zeolitite substrate 
containing phosphatic waste. Environmental Science and Pollution Research 21(23): 13, 237-242 (2014).

Leonard, J.J., Atlantic Richfield Co, 1981. Preparation of zeolite $A$ by hydrothermal treatment of clinoptilolite. U.S. Patent 4,247,524.

Li, J., Wee, C., and Sohn, B., Effect of ammonium- and potassium-loaded zeolite on kale (Brassica alboglabra) growth and soil property. American Journal of Plant Sciences 4:1976-1982 (2013).

Lija, W.B.M., Ahmed, O.H. and Kasim, S., 2012. Reducing ammonia volatilization from compound fertilizers amended with zeolite. African Journal of Biotechnology, 11(74), pp.1390313906.

Loizidou, M., and Kapetanios, E. G., Study on the gaseous emissions from a landfill. Science of the total environment, 127(3), 201-210 (1992).

Molla A., Ioannou. Z., Mollas S., Skoufogianni E., and Dimirkou A., Influence of Chromic Ions in Maize Cultivation (ZEA MAYS) after the addition of Natural minerals as Soil Amendments,Proceedings of the 14th International Conference on Environmental Science and Technology Rhodes, Greece, 3-5 September (2015).

Montemurro, F., Vitti, C., Diacono, M., Canali, S., Tittarelli, F. and Ferri, D., 2010. A three-year field anaerobic digestates application: effects on fodder crops performance and soil properties. Fresenius Environmental Bulletin, 19(9b), pp.2087-2093.

Muhlbachova, G. and Simon, T., 2003. Effects of zeolite amendment on microbial biomass and respiratory activity in heavy metal contaminated soils. Plant soil and environment, 49(12), pp.536-541.
Mumpton, F. A., La rocamagica: uses of natural zeolites in agriculture and industry. Proceedings of the National Academy of Sciences, 96(7), 3463-3470 (1999).

Noori, M., Zendehdel, M., Ahmadi, A., Using Natural Zeolite for the Improvement of Soil Salinity and Crop Yield. Toxicol. Environ. Chem., 88: 77-84 (2006).

Onagi, T., 1966. Treating Experiments of Chicken Dropping with Zeolitic Tuff Powder, 2 Experimental Use ZeoliteTuffs as Dietary Supplements for Chickens. Rep. Yamagata Stock Baising Inst, pp.7-18.

Oste, L.A., Lexmond, T.M. and Van Riemsdijk, W.H., 2002. Metal immobilization in soils using synthetic zeolites. Journal of Environmental Quality, 31(3), pp.813-821.

Öz S., Hepbaşlı A., Koçer G., Akar A., DoğalZeolitlerin (Klinoptilolit) ÜlkemizdekiKullanımOlanaklarıveEner jiUygulamaları". $1 . \quad$ Eg Enerji Sempozyumuve Sergisi, Mayıs, Pamukkale Üniversitesi, Mühendislik Fakültesi, Denizli., 132-137 (2003).

Park, M., and Komarnent, S., Ammonium nitrate occlusion vs. nitrate ion exchange in natural zeolites. Soil Sci. Am. J. 62, 1455-1459 (1998).

Perez-Caballero R, Gil J, Benitez C, Gonzalez JL., The effect of adding zeolite to soils in order to improve the $\mathrm{N}-\mathrm{K}$ nutrition of olive trees, preliminary results. Am. J. Agric. Biol. Sci., 2(1): 321-324 (2008).

Perrin, T.S., Boettinger, J.L., Drost, D.T. and Norton, J.M., Decreasing nitrogen leaching from sandy soil with ammoniumloadedclinoptilolite. Journal of Environmental Quality 27: 656-63 (1998).

Pisarovic, A., Filipan, T. and TISMA, S., Application of zeolite based special substrates in agriculture: ecological and economical justification. 
Periodicumbiologorum, 105(3), pp.287293 (2003).

Polat, E., Karaca, M., Demir, H., and Onus, A.N., Use of natural zeolite (clinoptilolite) in agriculture. Journal of fruit and ornamental plant research 12, no. 1: 183-189 (2004).

Rad, S., Hossein, A., Zeolite and nitrogen rates effect on some agronomic traits and fatty acids of winter rapeseed under non water and water stress conditions." International Journal of Science and Advanced Technology 1, no, 114-121 (2011).

Ramesh, K. and Reddy, D.D., 2011. Zeolites and their potential uses in agriculture. In Advances in agronomy (Vol. 113, pp. 219-241). Academic Press.

Ramesh, K., Biswas, A.K., Somasundaram, J., Rao, A.S., Non Porous Zeolite in farming: Current status and issue ahead, Current Science, Vol.99, No. 6, page 760-764 (2010).

Ramesh, K., Reddy, K.S., Rashmi, I., Biswas, A.K. and Islam, K.R., 2015. Does particle size of clinoptilolite zeolite have a role in textural properties? Insight through differential pore-volume distribution of Barret, Joyner, and Halenda Model. Communications in Soil Science and Plant Analysis, 46(16), pp.2070-2078.

Sepaskhah, A. R., and Barzegar, M. Yield, water and nitrogen-use response of rice to zeolite and nitrogen fertilization in a semi-arid environment. Agricultural Water Management, 98(1), 38-44 (2010).

\section{How to cite this article:}

Meharkure Mahesh, Jencymol Thomas, K. Arun Kumar, Balkrishna S. Bhople, N.V. Saresh, Sachin K. Vaid and Sanjat Kumar Sahu. 2018. Zeolite Farming: A Sustainable Agricultural Prospective. Int.J.Curr.Microbiol.App.Sci. 7(05): 2912-2924. doi: https://doi.org/10.20546/ijcmas.2018.705.340
Shinde, S.A., Telang, S.M., Patil S.S., and Baig, M.M.V., Effect of clinoptilolite zeolite on mushroom growth, An Asian Journal Of Soil Science (June 2010) Vol. 5 No. 1: 68-69 (2010).

Szerement, J., Ambrozewicz-Nita, A., Kedziora, K., and Piasek, J. Use of zeolite in agriculture and environmental protection. A Short review. UDC, 666(691.5) (2014).

Szerement, J., Ambrozewicz-Nita, A., Kedziora, K., and Piasek, J. Use of zeolite in agriculture and environmental protection. A Short review. UDC, 666(691.5) (2014).

Xiliang, H., Enxiang, Z., and Chun, J., A research of zeolite improving the structural property of soils. Journal of Hebei Agricultural University (China) (1991).

Yapparov, A.K., Bikkinina, L.K., Yapparov, I.A., Aliev, S.A., Ezhkova, A.M., Ezhkov, V.O. and Gazizov, R.R., Changes in the properties and productivity of leached chernozem and gray forest soil under the impact of ameliorants. Eurasian Soil Science, 48(10), 1149-1158 (2015).

Zalidis, G., Stamatiadis, S., Takavakoglou, V., Eskridge, K., and Misopolinos, N., Impacts of agricultural practices on soil and water quality in the Mediterranean region and proposed assessment methodology. Agriculture, Ecosystems \& Environment 88, no. 2:137-146 (2002). 